\title{
Scientific and Methodical Solutions of Long-Term Storage of Electronic Records in the Russian Federation
}

\author{
MIKHAIL V. LARIN, DR. PROF. \\ Director, All-Russian Scientific and Research Institute for Archives and Records Management (VNIIDAD), \\ Russia, Moscow, 117393, Profsoiuznaia ul., 82, www.vniidad.ru \\ e-mail: larin@vniidad.ru
}

Scientific and Methodical Solutions of Long-Term Storage of Electronic Records in the Russian Federation

ABSTRACT

The author has examined normative and methodical foundations of work with electronic records in records management of the Russian Federation and presented the solutions of their long-term storage based on experiences of the Russian archivists and records managers with electronic records.

Soluzioni metodologiche e scientifiche per la conservazione a lungo termine dei documenti in formato elettronico della Federazione Russa

\section{SINTESI}

In questo articolo l'autore ha esaminato le basi normative e metodologiche del lavoro sui documenti elettronici della Federazione Russa e le soluzioni per la loro archiviazione a lungo termine a partire dall'esperienza operativa degli archivisti russi e dei gestori di documenti elettronici.

Znanstvene in metodološke rešitve za dolgoročno hrambo elektronskega gradiva v Ruski federaciji

\section{IZVLE $\check{C E K}$}

Avtor v prispevku predstavlja zakonske in metodološke osnove za delo z elektronskim gradivom v Ruski federaciji in predstavlja rešitve za njegovo dolgoročno hrambo, ki so nastale na podlagi praktičnih izkušenj ruskih arhivistov in delavcev, ki delajo z dokumentarnim gradivom, pri delu z elektronskim gradivom.

Научно-методические решения долгосрочного хранения электронных документов в Российской Федерации

\section{АННОТАЦИЯ}

В докладе рассматриваются нормативно-методические основы организации работы с электронными документами в делопроизводстве РФ и решения их долгосрочного хранения на базе опыта работы российских архивистов и документоведов с эмектронными документами.

The problem of long-term storage of electronic records is actual in the Russian archival science and records management.

Recently in Russia, the important steps on studying and understanding peculiarities of electronic record from the point of view of records management and archival science, and also efforts on creation of normative and methodical regulation of intradepartmental and interdepartmental electronic records circulation have been undertaken.

The All-Russian scientific and research institute for archives and records management (VNIIDAD) under the Federal archival agency (Rosarhiv) has carried out a set of scientific works on studying electronic records, development of normative and methodical bases of work with electronic records in records management and organization of their long-term archival storage during last years . 
First of all, it was necessary to solve the problems of normative regulation of work with electronic records at records management stage.

Regulations on records management in federal executive authorities, N. 477, from June 15, 2009, were established by the Russian Federation Government in preparation of which VNIIDAD was an active participant.

Regulations were developed according to the article 11 of the Federal law from July 27, 2006, "On information, information technologies and information protection". They became the first normative document with main principles of work with electronic records in records management of federal executive authorities.

Now Regulations are the unique normative document establishing general requirements to organization of work with electronic records in records management of authorities. In a section of Regulations about peculiarities of work with electronic records, an important methodological principle was formed and realized. According to this principle the organization of work with records on paper and electronic records, both in records management and archives, is based on uniform methodology, but different technologies.

The most important provisions of Regulations are the following:

- electronic records are created, processed and stored in information system of electronic records circulation (SED) of federal executive authorities;

- electronic digital signatures, certificated in established order, are used for signing electronic records;

- obligatory data (metadata) about records (their list is in the appendix to Regulations) are used for control and search of records in SED, and also additional data about records can be used;

- complied electronic records are classified into files according to the filing system while making which it is indicated that a file is kept in electronic form (disposal dates of electronic records storage meet the disposal dates established for analogue records on paper).

At the same time a dictionary of terminology "Records management" and a standard GOST P 7.0.8-2013 "SIBID. Archives and records management. Terms and definitions" have been prepared for specialists in records and archives management.

Both documents contain terms in records management, including electronic records management process: electronic record, metadata, conversion, migration, file format, electronic records circulation (SED), etc.

Unlike state (municipal) archives for which regulations were approved in 2007, and they became a normative base for their activity, for a long time the archives of organizations didn't have similar normative document stating an order of records storage and records transfer for permanent storage to state and municipal archives.

Therefore, VNIIDAD has prepared Rules of storage, acquisition, control and use of records of the Russian Federation Archival fund and other archival records in state, local authorities and organizations. Now this document is at its final stage of registration in the Ministry of Justice of the Russian Federation.

VNIIDAD also has developed Recommendations on acquisition, control and organization of electronic archival records storage in archives of organizations and in state and municipal archives.

These Recommendations' goal is creation of uniform methodical and methodological basis of work with electronic records in archives of organizations, state (municipal) archives, including storage, acquisition and control of electronic records.

Recommendations apply to administrative electronic records, which are created, processed and stored in information systems of organization, subject to storage in organization's archives in established order and within disposal dates approved for analogue records on paper, including electronic records, which are to be transferred for storage to state (municipal) archives. 
In Recommendations' projects, there are two approaches for organization of transfer and storage of archival electronic records in archives of organizations, state and municipal archives: transfer and storage of electronic records on physically isolated material objects of single recording and transfer of electronic records by information-telecommunication channelling with further storage on servers of organization's archives, state (municipal) archives.

The special feature of long-term archival storage of electronic records is that electronic records are stored in two identical copies (main and working) in organization's archives, state (municipal) archives. The main copy represents itself as a reference copy and used for creation of a new working copy. The working copy is a copy used in archives for reproduction of electronic record, creation of a copy of electronic record for users and for any other cases.

Recommendations specify that with preparation of electronic records for transfer to storage in organization's archives they must be converted into PDF/A-1 format for archival storage. Then containers of electronic records are formed. The electronic records container is a packing included electronic record in a format of archival storage and its metadata, which is like a zip folder. There is an electronic record in PDF/A-1format, record's metadata in XML format, including a file (files) of digital signatures in the container of electronic record.

It is offered to archives to make conversion of electronic records to new formats and/or their migration on new carriers in case of hardware and software environment changes and computer formats being no longer in use, and also carriers' damages. Archives should have appropriate equipment, software and staff of qualified archivists for control of reproducibility of electronic records, conversion, migration and copying of electronic records, etc.

The Institute has developed archival science and records management' functional requirements to information systems providing electronic records circulation (SED) in the course of internal activity of federal executive authorities in order to unification and normative regulation of metadata, necessary for management of authentic, integral, valid and available for use records.

These Requirements includes description of basic records management' processes in SED, a scheme of classification and filing organization, general principles and requirements to the system, its applied functions, informational support, digital signature's use, search, representation and accountability, control, storage of information, administration and authorities' management, functioning of SED, a role model and users' training. An appendix to Requirements contains description of input forms fields (registration cards of records, classifiers and directories), providing identification of various groups of records and their management. Functional purpose of records data included in SED is defined in the appendix. There is a possibility of record's integration into information systems of organization' archives, at first, and, then, of state or municipal archives concerning the description of input forms fields.

Long-term storage of archival records is one more direction of the Russian Federation archival institutions' activity.

The most actual scientific researches in basic archival technology, technological processes and procedures of archival records storage are researches of digital technologies application for preservation and restoration of physical state of dying texts (images) of archival records on paper; working out typical technologies of correcting electronic textual archival records' damaged copies with creation of users' electronic fund; monitoring and development of recommendations about preventive measures on biological defeats and protection of archival repositories and archival records of state archives.

Application of modern information technologies by developing methods of evaluation of control and stabilization of traditional and electronic archival records' physical state is becoming the primary task within perfection of methodical solutions of technological processes on archival records storage.

Security copying plays a great role in the system of any archival records storage. It is necessary to improve methods of creation, availability and state control, technical control of security fund, and also creation of copies of users' fund in electronic form. 
Traditionally the main function of archives is storage of paper archival records. Now majority of documentation is created in electronic form, and volume of electronic records will increase in archives in due course. The ability to accept, keep and use becomes vital. Therefore, there is a great need to improve normative and methodical solutions of technological processes of electronic records storage.

VNIIDAD has prepared "Methodical Recommendations on electronic copying of archival records and management of created information files". They are based on up-to-date level of information technologies' development accessible to the Russian archives. These Recommendations include general approaches, principles and administrative mechanisms of digitalization projects, but they do not exclude certain variability in creation of electronic users' fund, taking into account adopted practice and possibilities in each archival institution. The description of technical parameters and equipment characteristics, mentioned in these Recommendations, will be relevant no more than 3 - 5 years. After the indicated date of expiry, they should be overworked in regular order as the result of occurred changes in technics and technologies development.

For a full-scale regulation of records' digitalization processes it is appropriate to create not one normative document regulating digitalization' questions, but a set of normative and legal acts containing requirements to all stages and aspects of this process which will be realized by experts in different fields.

In informatization plans of the Russian archives the following problems should be solved:

- development of additions to normative requirements on building, reconstruction, operation of buildings, premises (archival repositories, reading rooms, laboratories), taking into account electronic records storage;

- introduction of innovations in modern fire-fighting systems, automatic measurement of air environment parameters, information and logistical technologies, etc.

- detailed elaboration of structure of electronic record container transferred into archives, concerning metadata structure, needed for support of legal importance and records management in the course of its storage from organization's archives to state or municipal archives;

- description of XML-schemes of electronic records, subject to storage in organization's archives and in state (municipal) archives;

- formulation of requirements to information systems of organization's archives and state (municipal) archives, providing management of electronic archival records, including description of these systems' functions.

And, besides, it is necessary to rework and add appropriate sections to the existing and operating "Regulations of storage, acquisition, control and use of records of the Russian Federation Archival fund and other archival records in state and municipal archives, museums and libraries, organizations of the Russian Academy of Sciences" (M, 2007) in connection with specifications of work with electronic records and usage of modern information technologies in archives activity.

There is only a part of scientific and research directions in electronic records sphere mentioned in this report.

However, according to these developments we can make conclusions that the Russian scientists, engaged in long-term storage of electronic records, have done a considerable work, the results of which allow us not only research theoretically a phenomenon of electronic record, but also make archival recommendations on practical solutions of this problem.

\section{References}

Федеральный закон (2006) “Об информации, информационных технологиях и о защите информации”.

Правила делопроизводства в федеральных органах исполнительной власти, утверждены постановлением Правительства Российской Федерации (2009), N. 477.

Правияа организации хранения, комплектования, учёта и использования документов Архивного фонда 
Mikhail V. LARIN: Scientific and Methodical Solutions of Long-Term Storage of Electronic Records in the Russian Federation, 211-215

Российской Федерации и других архивных документов в государственных и муниципальных архивах, музеях и библиотеках, организациях Российской академии наук. М., Методические рекомендации по эмектронному копированию архивных документов и управлению полученным информационным массивом (2007), М., ВНИИААА.

ГОСТ Р 7.0.8-2013 “СИБИА. Аелопроизводство и архивное дело. Термины и определения” (2013), Росстандарт, ВНИИААА.

Аарин, М.В.,Янковая, В.Ф.(2014).ЭАектронные документы и научно-методическое обеспечение управления ими в делопроизводстве и архиве. М., Отечественные архивы, N. 3.

Зарубежный опыт управмения эмектронными документами и организации их архивного хранения. Аналитический обзор. Под редакцией М.В. Аарина. (2014). Федеральное архивное агентство. М., ВНИИААА.

\section{SUMMARY}

The problem of electronic records long-term storage is actual in the Russian archival science and records management. Important steps on studying and understanding the peculiarities of electronic record from the point of view of archival science, and also on normative and methodical regulation of internal and interdepartmental electronic records circulation were made lately. The All-Russian scientific and research institute for archives and records management (VNIIDAD) has performed a set of researches on studying electronic records, preparation of normative and methodical bases of work with electronic records in records keeping and their archival longterm storage. Recommendations on acquisition, control and storage of electronic archival records in organizations' archives and in state and municipal archives are the result of this work. The aim of these Recommendations' preparation is creation of a uniform methodical and methodological fundament of work with electronic records in archives. For the purpose of unification of electronic records circulation automated systems, VNII$\mathrm{DAD}$ has developed archival science and records management functional requirements to information systems providing electronic records circulation during the internal activity of federal executive authorities. In the whole the results of scientific and research works, carried out by the Institute, allowed to plan perspective directions of researches and tasks to be solved in the nearest future. They are the following:

- detailed elaboration of structure of electronic record container transferred into archives, concerning metadata structure, needed for support of legal importance and records management in the course of its storage from organization's archives to state or municipal archives;

- description of XML-schemes of electronic records, subject to storage in organization's archives and in state (municipal) archives;

- elaboration of requirements to information systems of organization's archives and state (municipal) archives, providing electronic archival records management, including description of these systems' functions.

Typology: 1.04 Professional Article

Submitting date: 12.03 .2015

Acceptance date: 09.04.2015 
